\title{
Subjunctive and Subject Obviation in Portuguese
}

Subject obviation refers to the impossibility of the subject of an embedded clause to be co-referent with the main clause's subject. This is verified in complementation structures of some predicates that select the subjunctive, but not in those of other predicates. A semantic explanation is proposed, based on Giannakidou's concept of veridicality, for why only some of the predicates that select the subjunctive mood trigger obviation.

\section{Introduction}

One aspect of complementation structures in pro-drop languages, as (European) Portuguese, that has received a great deal of attention is the (im)possibility of the subject of the embedded clause to be co-referent with the one of the main clause. A classical observation is that in subjunctive complement clauses the subjects of main and embedded clauses must have disjoint reference, while the subject of indicative complement clauses may be co-referent with the main subject:

(1) a. Quero ${ }_{i}$ que $[\mathrm{pro}]_{* \mathrm{i} / \mathrm{j}}$ saia cedo.

I want that [pro] leave-SUBJ.1.SG/3.SG early.

b. Ele conseguiu i $_{\mathrm{i}}\left[\mathrm{pro}{ }_{*_{\mathrm{i}} / \mathrm{j}}\right.$ fechasse o portão.

He managed that [pro] close-SUBJ.1.SG/3.SG the gate.

(2) a. Penso $\mathrm{i}_{\mathrm{i}}$ que $[\mathrm{pro}]_{\mathrm{i}}$ saio cedo.

I think that [pro] leave-SUBJ.1.SG early.

b. Ele lembra-se $e_{i}$ que [pro $]_{i}$ fechou o portão.

He remembers that [pro] closed-SUBJ.3.SG the gate. 
The fact that co-reference of the subjects is impossible in examples like (1) - a fact known as (subject) obviation -, but not in cases like (2), with the indicative, has been at the heart of an extensive bunch of literature in the field of syntax. From a semantic point of view (as Quer 1998 observes, obviation is an issue of semantic nature), the analyses of Farkas 1992 and Kempchinsky 2009 are landmarks. Both authors acknowledge that obviation is related to the meaning of the main predicate and (as observed previously by Ruwet 1984) to agentivity. The proposal of Kempchinsky 2009 will be discussed below. As for Farkas 1992's account, she proposes that obviation is a consequence of the availability of two kinds of complements (subjunctives and infinitives), together with general principles. In simple terms, the idea is that with certain predicates if the infinitive can be used it must be used. In this paper I will focus on data of Portuguese, trying to push a bit further this idea. Hopefully, a semantic account of mood can shed some light on why, in some cases but not others, the infinitive must be chosen over the subjunctive.

\section{Obviation and tense dependency}

Within the government and binding theory paradigm of Generative Syntax, several authors (e.g., Raposo 1985, Ambar 1992, a.o., for Portuguese; Picallo 1985, for Spanish) have proposed that the disjoint reference of subjects in subjunctive complementation structures follows from Principle B, according to which a pronoun must be free in its binding domain. These analyses explore the idea that subjunctive clauses are defective for tense features and, therefore, a subjunctive clause is a temporal domain dependent from the matrix clause. Consequently, the null subject of the embedded clause cannot be linked to the one of the matrix clause, in accordance to Principle B. On the contrary, indicative clauses would be specified for tense and the embedded clause forms a 
temporal domain independent from the matrix. Hence, the null subject of the embedded clause can be co-referent with the matrix one, because matrix and embedded clause are two distinct syntactic domains.

In sum, according to these analyses, obviation is a consequence of the temporal dependency of the subjunctive, together with Principle B. A common explanation is, then, provided for obviation and consecutio temporum in subjunctive complementation structures.

However, as observed by several authors, there are some fundamental problems for an analysis along these lines. Here I focus on two issues. First, temporal dependency is not always verified in subjunctive complementation structures. Hence, temporal dependency is not a characteristic of the subjunctive per se. Second, some indicative complementation structures also show restrictions on sequence of tenses (SOT), although no obviation effect is observed. Thus, obviation cannot be reduced to temporal dependency. Let us illustrate each of these problems.

Concerning the first problem, it has long been observed (cf., e.g., Kempchinsky 1986 for Spanish or Oliveira 2003 for Portuguese) that the tense sequence PAST + PRES is possible with directive predicates, alongside with the sequence PAST + PAST, the presence of present tense or past tense in the complement clause having real effects on the temporal interpretation, as illustrated by (3):

(3) a. A Ana pediu que fechasses a porta.

... fechaste-a?

'Ana asked that you close-PAST-SUBJ the door.'

'... did you close it?'

b. A Ana pediu que feches a porta.

... \#fechaste-a? 
'Ana asked that you close-PRES-SUBJ the door.'

'... \#did you close it?'

In (3a) the sequence of tenses PAST (in the main clause) + PAST (in the embedded clause) is observed, while (3b) shows the sequence PAST + PRES. While in (3a) the temporal perspective point (TTP) for the embedded tense is the time of the main event (that is, the event of closing the door is futurate concerning the event of Ana's asking, not necessarily futurate concerning utterance time), in (3b), the TPP for the embedded tense is utterance time, as shown by the impossibility of continuing the sentence with (the equivalent of) "did you close it?". Thus, the subjunctive tense does not have to be harmonic with the main tense (i.e., in the subjunctive complement, a present tense, which takes utterance time as its TPP, is compatible with a past tense in the main clause).

The same is observed in structures with factive subjunctive verbs (cf. (4a-b)) and implicative verbs (cf. (4c)):

(4) a. Surpreendeu-me que ele seja / fosse tão alto!

'I was surprised (PAST) that he is (PRES-SUBJ) / was (PAST-SUBJ) so tall!'

b. Até ontem, sempre lamentei que ela more / morasse no estrangeiro.

'Until yesterday, I always regretted (PAST) that she lives (PRES-SUBJ) / lived (PAST-SUBJ) abroad.'

c. A construção da ponte, há dois anos atrás, permitiu que possamos / pudéssemos atravessar o rio a pé.

'The construction of the bridge, two years ago, allowed (PAST) that we can (PRES-SUBJ) / could (PAST-SUBJ) cross the bridge.' 
Moreover, the sequence PRES + PAST is possible in some structures of subjunctive complementation:

(5) Ontem, houve uma explosão naquele prédio. Espero que não estivesse ninguém lá dentro!

'Yesterday there was an explosion in that building. I hope (PRES) that nobody was (PAST-SUBJ) inside!'

This data shows that subjunctive complementation does not necessarily involve tense dependency on the main clause. It seems more defensible that subjunctive tenses have semantic import, just like the indicative tenses, as argued by, e.g., Vogel 1997 or Laca 2007 for other Romance languages. Present subjunctive has utterance time $\left(\mathrm{t}_{0}\right)$ as its TPP and past subjunctive accepts as its TPP the temporal location of the event described by the main clause. Tense harmony between embedded and main clause is obligatory with complements of predicates of volition (or desiderative predicates), as querer ('to want'), but is not required with any subjunctive complementation structure. In fact, concerning sequence of tenses, three groups of subjunctive predicates have to be considered:

(i) predicates that accept both the sequence PAST + PRES and PRES + PAST: factiveemotive predicates, like lamentar ('to regret'), surpreender-se ('to be surprised'), etc.

(ii) predicates that accept the sequence PAST + PRES, but not PRES + PAST: implicative (e.g., conseguir 'to manage') and deontic predicates (e.g., mandar 'to order' or pedir 'to ask');

(iii) predicates that accept the sequence PRES + PAST, but not PAST + PRES: esperar ('to hope'), duvidar ('to doubt'); 
(iv) predicates that impose tense harmony (i.e., only accept the sequence PRES + PRES or PAST + PAST): predicates of volition (e.g., querer 'to want', desejar 'to desire').

Table I summarizes these observations:

\begin{tabular}{|l|c|c|c|}
\cline { 2 - 4 } \multicolumn{1}{c|}{} & PAST + PRES & PRES + PAST & \multicolumn{1}{c|}{} \\
\hline lamentar ('regret') & ok & ok & (a) \\
\hline pedir, mandar, & ok & $*$ & \\
conseguir ('ask, & & & \\
'order', 'manage') & & & (c) \\
\hline esperar, duvidar & $*$ & & \\
('hope', 'doubt') & & & (d) \\
\hline querer ('want') & $*$ & & \\
\hline
\end{tabular}

Table I - Subjunctive predicates and SOT

(a) Lamentei que estejas desempregado. / Lamento que estivesses desempregado. 'I regretted (PAST) that you are (PRES-SUBJ) unemployed. / I regret (PRES) that you were (PAST-SUBJ) unemployed.'

(b) Ele pediu que fales com a Ana. / *Ele pede que falasses com a Ana.

'He asked (PAST) that you speak (PRES-IND) with Ana. / *He asks (PRES) that you spoke (PAST-SUBJ) with Ana.'

(c) *Duvidei que a Ana esteja mesmo doente. / Duvido que a Ana estivesse mesmo doente.

'*I doubted (PAST) that Ana is (PRES-SUBJ) really ill. / I doubt (PRES) that Ana was (PAST-SUBJ) really ill.’ 
(d) Ele quis que a Ana lhe $\{*$ telefone / telefonasse $\}$. / Ele quer que a Ana lhe \{telefone / *telefonasse\}.

'He wanted (PAST) that Ana \{phone (*PRES-SUBJ) / (PAST-SUBJ) $\}$ him. / He wants (PRES) that Ana \{phone (PRES-SUBJ) / (*PAST-SUBJ) $\}$ him.'

Considering now indicative complement clauses, the same kind of picture is noted: with some verbs no restrictions are observed concerning sequence of tenses, contrary to what happens with other indicative verbs. With declaratives and epistemic factive verbs, as saber ('to know'), all tense sequences are allowed (cf. (6)), while with verbs as prometer ('to promise') the sequence PRES + PAST is, obviously, ruled out (cf. (7)), and with doxastic verbs like achar ('to think') or supor ('to suppose') the sequence PAST + PRES is blocked (cf. (8)):

(6) a. Ele $\{$ diz / disse $\}$ que $\{$ está / estava / esteve ... $\}$ doente.

'He $\{$ says / said $\}$ that he $\{$ is / was-PAST-IMPF / -PAST-PERF ... $\}$ ill.'

b. $\{$ Sei / Soube $\}$ que ele $\{$ está / estava / esteve ... $\}$ doente.

'I $\{$ know / knew $\}$ that he $\{$ is / was-PAST-IMPF / -PAST-PERF ... $\}$ ill.'

(7) Prometo que $\{$ chego / * cheguei $\}$ a horas.

'I promise that I \{arrive-PRES / *arrived-PAST\} on schedule.'

(8) Achei que a Ana $\{$ estava / *está $\}$ doente.

'I thought that Ana \{is-PRES / *was-PAST $\}$ ill.'

Table II summarizes these observations: 


\begin{tabular}{|c|c|c|}
\hline & PAST + PRES & PRES + PAST \\
\hline dizer, saber ('say', 'know') & ok & ok \\
\hline prometer ('promise') & ok & $*$ \\
\hline achar ('think') & $*$ & ok \\
\hline
\end{tabular}

Table II - Indicative predicates and SOT

The comparison of tables I and II shows that, both in the class of subjunctive rulers as in the class of indicative rulers, there are predicates that impose SOT restrictions and predicates that do not. Thus, as observed in, e.g., Marques 2014 or Marques et al. 2015, restrictions on sequence of tenses are imposed by the matrix verb (i.e., it is a lexical matter), and affect both verbs that select the subjunctive as verbs that select the indicative. The hypothesis that subject obviation is a consequence of some kind of temporal defectiveness of the subjunctive does not fit well with the observation that SOT restrictions are lexically driven and independent of the mood selected by the main predicate.

Finally, the idea that obviation is a consequence of tense dependency faces the problem that co-reference of embedded and main subjects may coexist with tense restrictions. This is observable in constructions with indicative complement clauses, such as (9a), and also in constructions with subjunctive complements, as (9b):

(9) a. Ele ${ }_{\mathrm{i}}$ achou que $[-]_{\mathrm{i}}$ tinha / *tem tempo.

'He $\mathrm{i}_{\mathrm{i}}$ thought (PAST) that he $\mathrm{i}_{\mathrm{i}}$ had (PAST-IND) / *has (PRES-IND) time.'

b. $[-]_{\mathrm{i}}$ Duvidei que $[-]_{\mathrm{i}}$ conseguisse $/ *$ consiga $[-]_{\mathrm{i}}$ chegar a tempo.

'I doubted (PAST) that I managed (PAST-SUBJ) / *manage (PRES-SUBJ) arrive on schedule.' 
In these examples, the embedded tense has to concord with the one of the main clause. However, embedded and main subjects are co-referent, a fact that shows that tense dependency does not lead to subject obviation.

In synthesis, though the idea that obviation follows from tense dependency of the subjunctive clauses allows an elegant description of structures like (1) - Quero que $[-]_{*_{i} / j}$ saia cedo (' $I_{\mathrm{i}}$ want that $[-]_{*}$ ij leave-SUBJ.1.SG/3.SG early') - , it faces empirical objections: subjunctive tenses express temporal information, just like indicative tenses; restrictions on tense sequences in complementation structures are observed both in cases with the subjunctive and in cases with the indicative; it is not the case that obviation is obligatory whenever there must exist (some kind of) tense concord between complement and main clause. The observed data shows that there are three autonomous, even if related, issues: subjunctive complementation, restrictions on tense sequences, and obviation. Sentences like (1) may suggest that these issues are all connected, but the idea that obviation is a consequence of tense dependency, which, in turn, is a characteristic of the subjunctive, does not seem tenable.

The following table shows that these three issues - mood selection, SOT restrictions and obviation - are lexically constrained and that only with verbs of volition there is obligatory tense concord and obviation in subjunctive complementation structures. The first column in shadow concerns the mood of the complement clause (only finite clauses are considered, infinitival complementation is possible with all the considered verbs). The next two columns relate to the possibility of the present tense to occur in the embedded clause when the subordinating clause is in the past and viceversa. The last column refers to the impossibility of co-reference between the subjects of embedded and main clause (* means that co-reference is possible; i.e., no obviation): 


\begin{tabular}{|l|l|c|c|c|c|}
\hline Verb classes & \multicolumn{1}{|c|}{ Examples } & Mood & PAST + PRES & PRES + PAST & obviation \\
\hline Commissive & prometer 'to promise' & Ind. & $\sqrt{ }$ & $*$ & $*$ \\
\hline Declarative & dizer 'to say' & Ind. & $\sqrt{ }$ & $\sqrt{ }$ & $*$ \\
\hline Doxastic & achar 'to think' & Ind. & $*$ & $\sqrt{ }$ & $*$ \\
\cline { 2 - 6 } & duvidar 'to doubt' & Subj. & $*$ & $\sqrt{ }$ & $*$ \\
\hline \multirow{2}{*}{ Factive } & saber 'to know' & Ind. & $\sqrt{ }$ & $\sqrt{ }$ & $*$ \\
\cline { 2 - 6 } & lamentar & Subj. & $\sqrt{ }$ & $\sqrt{ }$ & $*$ \\
\hline Implicative & conseguir 'to manage' & Subj. & $\sqrt{ }$ & $*$ & $\sqrt{ }$ \\
\hline Deontic & pedir 'to ask' & Subj. & $\sqrt{ }$ & $*$ & $\sqrt{ }$ \\
\hline Volitive & querer 'to want' & Subj. & $*$ & $*$ & \\
\hline
\end{tabular}

Table III - Mood selection, SOT restrictions and obviation

As shown in table III, only verbs of volition, directives, and causatives are obviative predicates. All of these verbs are subjunctive rulers, but there are other subjunctive rulers which do not lead to subject obviation. Verbs of volition impose tense harmony between embedded and main clause, but not the other obviative predicates, which accept the sequence PAST + PRES. The considered data concerns only Portuguese. But the classes of verbs with which obviation holds - verbs of volition, directives, and causatives - are the same in other Romance languages, as has been observed in the literature. A proposal for why these verbs show obviation effects is found in Kempchinsky 2009, to which I now return.

\section{Obviation and the quasi-imperative operator - Kempchinsky's proposal}


Departing from her previous work, Kempchinsky 2009 characterizes subjunctive complement clauses of desiderative and directive predicates as embedded imperatives. She proposes that these subjunctive clauses have a quasi-imperative operator, located in the head of FinP, which yields an interpretation "anyone other than the matrix subject" (Kempchinsky 2009: 1796) (while true imperatives yield an interpretation "anyone other than the speaker''). Obviation in subjunctive complements to desiderative and directive predicates will then be due to the role that this quasi-imperative subjunctive operator plays in the interpretation of the embedded subject. In addition, she proposes, following Speas 2004, that in the syntactic representation there is a world argument which denotes the set of possible worlds within which the proposition expressed by a sentence is evaluated (i.e., the semantic notion "model of evaluation", see Giannakidou 1998 and her subsequent work, is represented in syntax). By default, the value of this argument will be the actual world and the model of evaluation corresponds to the speaker (i.e., the world in which the proposition is assigned a truth value is the epistemic model of the speaker; see Giannakidou 1998). In contrast, intensional predicates, as directives and verbs of volition, which typically select for subjunctive complements, introduce a set of future worlds which are anchored to the matrix subject (cf. also Farkas 1992, Giannakidou 1998).

Basing on these ideas, Kempchinsky 2009 proposes the syntactic structure (10) for subjunctive complements of verbs of volition and directives:

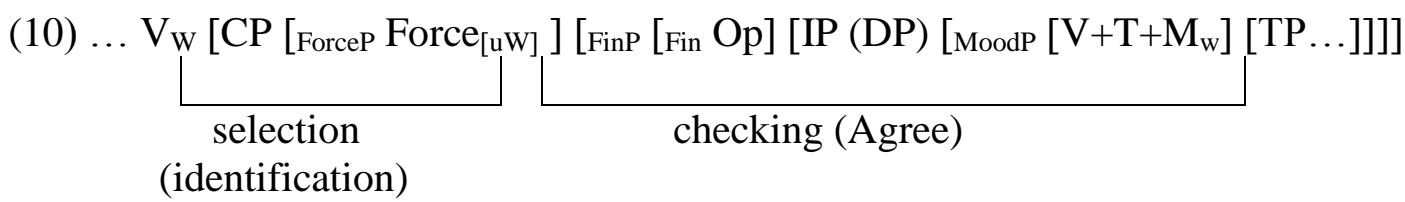


Just as lexical selection for an interrogative complement is expressed as an uninterpretable wh-feature in the CP field (...), we can suppose that lexical selection for a subjunctive complement is expressed as an uninterpretable $\mathrm{W}$ feature, in Force. As an uninterpretable feature, it must be checked and deleted, and the necessary interpretable feature to do this work, in a language with mood paradigms, is in Mood. More accurately, the complex head $[[[\mathrm{V}] \mathrm{T}] \mathrm{M}]$ in Mood checks, via Agree, the uW feature in Force.

(Kempchinsky 2009, p.1798)

In the case of negative clauses as (11), the complement clause can be evaluated either with respect to the epistemic model of the speaker or to the epistemic model of the main clause's subject, as shown by the two possible continuations of the sentence:

(11) The dean doesn't believe that the students deserve a prize $\ldots$ and neither do I. ... but I do.

In Spanish and Catalan, this model shift is signaled by mood shift, as observed by Quer 1998. The same is verified in Portuguese:

(12) a. Ele não acredita que a Maria seja cubana. ... e eu também não. /... \#mas está enganado. 'He does not believe that Maria is (Subj) Cuban.' '... and neither do I. / ... \#but he is wrong.'

b. Ele não acredita que a Maria é médica. ... \#e eu também não. / ... mas está enganado. 
'He does not believe that Maria is (Subj) Cuban.'

'... \#and neither do I. / ... but he is wrong.'

For these cases, where the subjunctive is not lexically selected (i.e., cases of "polarity subjunctive”, cf. Quer 1998), Kempchinsky proposes the following syntactic representation:

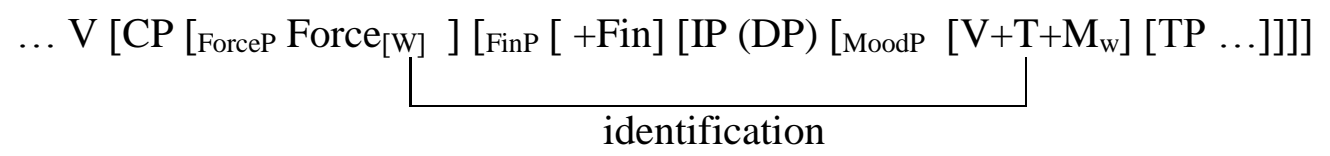

She argues that in both (10) and (13), the feature W must be identified:

In the case of lexically selected subjunctive, the shift in the modal base the introduction of a new (set of) possible worlds - is a consequence of the semantics of the matrix predicate. The selection relation itself triggers the presence of $\mathrm{W}$. Therefore, $\mathrm{W}$ itself is uninterpretable, and so like any other uninterpretable feature must be checked. In (27) [13], in contrast, the shift in the modal base is only made visible by the subjunctive mood itself; hence the relationship between $\mathrm{W}$ in Force and the verbal complex is not checking, but identification. (Kempchinsky 2009, p.1799)

Apart from these cases, Kempchinsky also considers the subjunctive in complement clauses of credere ('to believe') in Italian, where this mood is usually referred to be the most common, as well as in complement clauses of implicatives, like the equivalents of to manage or to force, and of factive-emotive predicates, like the equivalents of to regret. For all these cases, she argues that the selection of mood is due to the expression 
of some change in the modal base. Concerning the Italian data, she follows Giorgi and Pianesi 1997 in the assumption that «the default modal base for this proposition [the complement of credere] is $\mathrm{W}(\mathrm{Su})$, and this modal base has been grammaticalized in Italian» (Kempchinsky 2009, p. 1804). As for implicatives, she adheres to Quer's proposal that such predicates establish «a world dependency in which the main clause subject introduces a set of future alternatives right before the point of causation» (Quer 1998: 49). Implicative predicates, thus:

«group with strong intensional predicates such as desideratives in their common lexical property of introducing a set of future alternative worlds, complements to implicatives are evaluated in the non-veridical model $\mathrm{ME}_{\text {fut }}(\mathrm{su})$; that is, future realizations of the world according to the matrix subject and in which that subject wants - and in the case of implicatives brings about - a certain state of affairs. Given that it is a lexical property of the matrix verb that introduces this set of alternative worlds, by the logic of the account thus far this entails that the $\mathrm{W}$ feature in Force of the subjunctive complement is uninterpretable. Further, given the obviation facts, the quasi-imperative operator must also be present in Fin, with the usual consequences for interpretation of the subjunctive subject.»

(Kempchinsky 2009, p.1805)

Likewise, concerning factive-emotive predicates, she observes that:

«Traditional and pedagogical grammars of Spanish, in their attempts to explain the appearance of subjunctive complements with these predicates, ap- 
peal to the evaluative rather than the factive component of the main predicate. Quer (2001:107) has a specific articulation of this idea: factiveemotive predicates "express a causal link between an eventuality ... and a psychological state resulting from that eventuality" (cf. Giorgi and Pianesi, 1997).» (ib., 1807)

In sum, Kempchinsky proposes that the classical distinction between intensional subjunctive and polarity subjunctive (cf. Quer 1998) is reflected on syntax, and basing on Quer 1988, that subjunctive expresses some change in the modal base:

«to the extent that selection for a subjunctive clause - expressing some change in the modal base - becomes grammaticalized with other classes of matrix predicates (positive epistemics in Italian, factive-emotives in Romance in general), the $\mathrm{W}$ feature in Force becomes uninterpretable, to be checked and deleted by the V in Mood in the complement clause itself.»

$$
\text { (ib., p.1808) }
$$

In the cases of intensional subjunctive (i.e., when the subjunctive is lexically selected), obviation would occur, because of the presence of the quasi-imperative operator in the complement clause, but not in the cases of polarity subjunctive, where no such operator is present and identification, not checking (agree), would arise (cf. the representations (10) and (13), above).

The idea that verbs of volition and directives (as well as, possibly, other subjunctive predicates, as implicatives, as Kempchinsky assumes) are associated with a quasiimperative operator would explain Quer's generalization that for co-reference of embedded and main subjects to be possible "the subject of the matrix predicate cannot be 
the agent in control of the embedded eventuality" (Quer 1998: 51). However, there are some issues that lead to question Kempchinsky's explanation of obviation.

The first concerns the distinction between intensional and polarity subjunctive, which Kempchinsky integrates in the syntactic calculus. As seen, she observes a positive relation between obviation and intensional subjunctive. That is, according to her, obviation occurs when the subjunctive is lexically selected, but not in cases of polarity subjunctive, where, following Quer 1998, the subjunctive would signal a model shift. Though it seems unquestionable that the use of the indicative or the subjunctive in cases

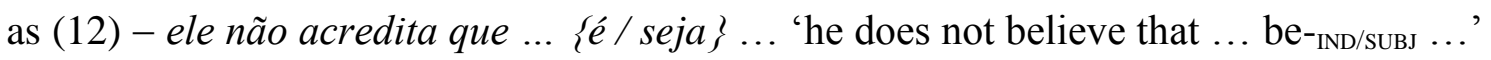
-, as in other cases discussed by Quer 1998, is related to model shift, it does not seem to be the case that the possibility of using the subjunctive or the indicative in the same context is always related to model shift, at least concerning Portuguese. In fact, in this language, the equivalent of believe and a group of verbs with the same core meaning (e.g., presumir, 'to presume', imaginar 'to guess') allow both the indicative and the subjunctive in the complement clause and no model shift is associated with any of the options:

(15) a. Acredito que há vida fora da Terra.

... tenho quase a certeza de que há!

... \#mas não estou muito convencido de que haja mesmo.

'I believe that there is- ${ }^{-}$ND alien life.'

'... I am almost sure that there is!'

'... \#but I'm not quite convinced that indeed there is.'

b. Acredito que haja vida fora da Terra.

... \#tenho quase a certeza de que há! 
... mas não estou muito convencido de que haja mesmo.

'I believe that there is-suвs alien life.'

'... \#I am almost sure that there is!'

'... but I'm not quite convinced that indeed there is.'

In these examples, whether the indicative or the subjunctive is used in the complement clause, only an epistemic model is considered, the one of the main clause's subject, which corresponds to the speaker. Moreover, as shown by the continuations of the discourse, when the indicative is used a higher degree of belief is expressed than when the subjunctive is selected. That is, in (15b) the subjunctive is not lexically selected (the indicative is also acceptable, as shown by (15a)) and no model shift is involved. The modal base considered in (15a) and (15b) is the same: the set of propositions forming the belief model of the attitude holder (see Giannakidou 1998). Therefore, (15b) is problematic for the syntactic calculus proposed by Kempchinsky: there would be no checking (agree), because the subjunctive is not lexically selected, but identification would also not occur because there is no model shift.

One might propose that the value of $\mathrm{W}$ (cf. the syntactic representations (10) and (13)) is not related to the model of evaluation but to something else. Another argument contrary to the idea that $\mathrm{W}$ signals the model of evaluation is the fact that indicative complement clauses are also evaluated towards a model, which might be different from the model of evaluation of the speaker:

(16) a. Ele disse que estava doente, mas mentiu.

'He said that he was- ${ }_{\text {IND }}$ ill, but he lied.'

b. Ele previu que iria chover, mas enganou-se. 
'He predicted that it would- ${ }_{\text {IND }}$ rain, but he was wrong.'

In sum, the consideration of a model of evaluation occurs with any complement clause of a propositional attitude predicate, regardless the mood of such complement. Hence, the relation between subjunctive, model of evaluation and obviation that Kempchinsky proposes is questionable. She argues that predicates selecting subjunctive also force a shift in the model of evaluation and select a quasi-imperative operator. As shown by data as (15) and (16), the shift in the model of evaluation (from the epistemic model of the speaker to a model anchored to the entity referred by the main clause's subject) does not occur only in the case of lexically selected subjunctive. So it is not a particularity of the obviative predicates (verbs of volition, directives and causative predicates).

A second problem with Kempchinsky's proposal is related to lexically selected subjunctive. She assumes the distinction between polarity subjunctive and lexically selected subjunctive and argues that subjunctive rulers in one way or another are associated with a quasi-imperative operator. However, for some lexically selected subjunctives there is no way to assume a quasi-imperative operator, as I will now try to show.

Kempchinsky argues that the core case of subjunctive complements are embedded imperatives (the distinction between these subjunctives and true imperatives being that the latter yield an interpretation "'anyone other than the speaker', while embedded imperatives yield an interpretation "'anyone other than the matrix subject'). In her terms:

"the core case of subjunctive complements are those which appear with matrix verbs which introduce some set of alternative worlds which do not hold 
at the time of the matrix predicate; this broad definition includes desideratives, directives and implicatives" (Kempchinsky 2009:1808).

This characterization is not applicable to all kinds of lexically selected subjunctive. Predicates like esperar ('to hope'), temer ('to fear'), recear ('to be afraid') or duvidar ('to doubt') are subjunctive rulers (i.e., the following are not cases of 'polarity subjunctive'), but, unlike desideratives, directives and implicatives, they are not future oriented:

(17) a. [- $]_{\mathrm{i}}\{$ Espero / temo / receio / duvido $\}$ que ele tenha saído cedo.

'I \{hope / fear / am afraid / doubt $\}$ that he left early.'

b. * $\{$ Quero / peço / consigo $\}$ que ele tenha saído cedo.

'*I \{want / ask / manage $\}$ that he left early.'

Thus, the subjunctive complements of predicates like esperar ('to hope'), duvidar ('to doubt') or verba timenda (temer 'to fear', recear 'to be afraid') are not embedded imperatives, though the subjunctive is lexically selected.

If these subjunctives are not embedded imperatives, the quasi-imperative operator will not be present, according to Kempchinsky's proposal, and co-reference of subjects should be possible. Portuguese data confirms this prediction (cf. (18)), though in the case of esperar ('to hope) and verba timenda co-reference is harder when the matrix subject is the agent (or controller) of the embedded eventuality (cf. (19a)):

(18) a. $[-]_{i}$ Espero que $[-]_{i}$ chegue a tempo.

'I hope that I arrive-subs on schedule.'

b. Ele ${ }_{i}\{$ receia / teme $\}$ que $[-]_{i}$ não consiga ver o filme. 
'He is afraid that he does not manage-suBj to see the movie.'

c. $[-]_{\mathrm{i}}$ Duvido que $[-]_{\mathrm{i}}$ acabe o trabalho no prazo.

'I doubt that I finish-subs the work on schedule.'

(19) a. $[-]_{\mathrm{i}}\{$ Espero / receio / temo $\}$ que $[-]_{*_{\mathrm{i}}}$ não vá à festa.

'I \{hope / am afraid \} that I will not go-subs to the party.'

b. $[-]_{\mathrm{i}}$ Duvido que $[-]_{\mathrm{i}}$ vá à festa.

'I doubt that I go-subs to the party.'

The point is that the quasi-imperative operator, that would cause obviation, is not present in all cases of lexically selected subjunctive. The only alternative would be to consider that it is lexically selected. Some predicates (directives, verbs of volition and causatives) would select embedded imperatives, with the quasi-imperative operator, and other predicates (e.g., the equivalents of to hope or to doubt) would select a different kind of subjunctive. This would force the consideration that several kinds of subjunctive occur in the same language (polarity subjunctive, in cases where the subjunctive is not lexically selected, and two kinds of lexically selected imperatives). But, apart from being theoretically more interesting having a unified analysis of all cases of subjunctive, there is no independent evidence, apart from obviation data, that points to the existence of different kinds of lexically selected subjunctives. Moreover, data as (19a) is problematic for Kempchinsky's analysis: if the subjunctive predicate is not an embedded imperative, the obviation could not be explained as following from the presence of the quasiimperative operator.

Finally, if the justification for obviation is the presence of the quasi-imperative operator and this operator is lexically selected, it should be present also in infinitival com- 
plements of the same predicates. But, with infinitival complements, co-reference is obligatory:

(20) Ele $_{\mathrm{i}}\{$ quis / pediu para / conseguiu $\}[-]_{\mathrm{i} / * \mathrm{j}}$ sair mais cedo.

'He $\{$ wanted / asked to / manage $\}$ to leave- ${ }_{\mathrm{INF}}$ earlier.'

In sum, in one hand the hypothetical quasi-imperative operator would be present only in some cases of lexically selected subjunctive, which suggests that it is lexically selected. On the other hand, this operator would be present only in subjunctive complements of some kinds of predicates, and not in infinitival complements of the same predicates. Thus, the account for obviation seems to be circular: obviation is observed in subjunctive complements of directives, verbs of volition and causatives because these predicates would select a quasi-imperative operator when their complement is in the subjunctive, and the evidence for the presence of this operator is that obviation occurs.

In other words, the idea that lexically selected subjunctives are embedded imperatives and, therefore, force obviation doesn't seem to be defensible for all cases of lexically selected subjunctive. Moreover, as seen above, the proposal that non-lexically selected subjunctives always signal a shift in the modal base is contradicted by data of Portuguese (cf. 15)). Finally, as Giannakidou (p.c.) observes, the idea that complements of (the equivalents of) want are embedded imperatives is problematic. Embedded imperatives appear in quotations, but not complements of want, neither complements of causative predicates, one might add:

(21) a. She told me: Open the door!

b. *She wanted: Open the door! 
c. *She managed: Open the door!

In the next sections, I will consider an analysis of subjunctive that does not assume the existence of different kinds of subjunctive and try to figure out whether such analysis can shed some light on this question.

\section{Subjunctive and non veridicality}

In her PhD dissertation and a lot of subsequent work, Giannakidou shows that subjunctive, both in Modern Greek as in other languages, signals non-veridicality. Her concept of (non) veridicality, which I adopt, does not correspond to factivity. A factive proposition is one that describes a fact of the real world. If $\varphi$ is a factive operator and $\varphi$ introduces a proposition $p$, then $\varphi p$ implies that $p$ is true in the real world. For instance, to know that $\mathrm{p}$ or to find out that $\mathrm{p}$ implies that $p$ is true in the real world (that $p$ is a fact). That is, verbs as to know or to find out are factive operators. Other propositional operators do not allow the inference that the proposition they introduce is true in the real world, but allow the inference that such proposition is true according to an entity. For instance, John thinks that there is a ghost at his attic does not allow the inference that in fact there is a ghost at John's attic, but it allows the inference that the sentence there is a ghost at John's attic is true for John. So, to think $p$ is not a factive predicate, but it is veridical: it allows the inference that the complement proposition is true for the attitude holder. Other veridical, and non-factive, verbs are, for instance, to say, to promise, to claim or to infer. All of these verbs indicate that their complement propositions are true to the attitude holder (John in this example). So, $x$ \{thinks / says / claims / ... that $\mathrm{p}$ indicates that $p$ is true for someone. Factive predicates are also veridical. John knows that 
the earth is round allows the inference that in reality the earth is round (i.e., to know is a factive verb) and also the inference that John takes this sentence to be true (i.e., to know is a veridical verb). Other factive predicates do not allow the inference that the attitude holder assumes that the complement clause is true, but they allow the inference that the speaker takes the sentence to be true. This is the case of predicates like to be unaware that $p$. These predicates are also veridical. They also allow the inference that the complement clause is true for someone. Thus, all factive predicates are veridical, but not all veridical predicates are factive (factive operators are a subset of veridical predicates).

Nonveridical operators do not allow the inference that the proposition under their scope is true according to someone. This is the case of, e.g., predicates like want, hope, order, be possible, and so on. A subclass of non veridical operators are anti-veridical operators, which allow the inference that the proposition they introduce is false. Predicates like to prevent or sentential negation are examples of anti-veridical operators:

(21) a. Snow prevented the hikers from reaching the end of the road. $\Rightarrow$ The hikers did not reach the end of the road.

b. She left without saying goodbye. $\Rightarrow$ She did not say goodbye.

In sum, veridical operators allow the inference that the proposition they introduce is true according to someone, non-veridical operators do not allow such inference, and antiveridical operators allow the inference that it is false (hence, anti-veridical operators are also non-veridical, they do not allow the inference that their complement proposition is true according to some individual). 
Giannakidou's, notion of (non) veridicality explores the idea that the truth value of a proposition is relativized. A sentence is not true or false in itself ${ }^{1}$, it is true (or false) for someone (Giannakidou uses the terms "relativize veridicality" or "subjective veridicality"). More precisely, the truth value of a sentence is relativized to a model of evaluation, a model being a set of possible worlds. For instance, in the sentence John thinks that there is a ghost at his attic the complement clause is evaluated against the set of worlds that conforms to John's beliefs and the sentence expresses the information that in all these worlds there is a ghost at John's attic. With verbs like to dream, the model against which the complement proposition is evaluated corresponds to the dreamworlds, and so on.

Giannakidou 2015 presents formal definitions of veridical and non-veridical operators:

«Def. 3. Subjective veridicality

A function $F$ that takes a proposition $p$ as its argument is subjectively veridical with respect to an epistemic state $\mathrm{M}(i)$ of an individual anchor $i$ iff:

(i) $F p$ entails or presupposes that $i$ knows/believes that $p$ is true.

(ii)If $i$ knows / believes that $p$, then $i$ 's epistemic state $\mathrm{M}(i)$ is such that: $\mathrm{M}(i)$ $\subseteq \mathrm{p}$

From Def. 3, it follows that $\forall \mathrm{w}\left[\mathrm{w} \in \mathrm{M}(i) \rightarrow \mathrm{w} \in\left\{\mathrm{w}^{\prime} \mid \mathrm{p}\left(\mathrm{w}^{\prime}\right)\right\}\right]$. Subjectively veridical functions require in their truth conditions homogenous epistemic $\underline{\text { states, }}$ included in $p$. This is the state of full commitment.» (Giannakidou 2015, p. 15, my underline)

\footnotetext{
${ }^{1}$ Leaving aside tautologies and contradictions.
} 
«Def. 4. Subjective nonveridicality

A function $F$ that takes a proposition $p$ as its argument is subjectively nonveridical with respect to an individual anchor $i$ iff:

(i) $F p$ does not entail that $i$ knows or believes that $\mathrm{p}$ is true.

(ii) $i$ 's epistemic state $\mathrm{M}(i)$ is such that: $\mathrm{M}(i)-\mathrm{p}$ is not $\emptyset$, which means that (iii) $\exists w^{\prime} \in M(i): \neg p\left(w^{\prime}\right)$.

A subjectively nonveridical function imposes non-homogeneity on the epis$\underline{\text { temic state, }}$ since there is at least one non-p world.» (Giannakidou 2015, pp. 16-17, my underline)

In sum, a veridical operator that takes a proposition $p$ as its argument introduces a homogeneous logical space, formed only by $p$-worlds, worlds where the state of affairs described by the proposition is not verified (if John thinks that Mary is ill, in all worlds that form John's epistemic model Mary is ill), whereas a non-veridical operator introduces a logical space where there is at least one non- $p$ world (if John doubts that Mary is ill, in at least one of the worlds that form John's epistemic model Mary is not ill; i.e., there is at least one non- $p$ world in John's epistemic model).

As shown in Giannakidou 1998, 2013, 2015, a.o., subjunctive occurs in nonveridical contexts. In other words, subjunctive signals that there is at least one non- $p$ world in the logical space where the subjunctive clause occurs.

One problem for Giannakidou's proposal that subjunctive signals nonveridicality is the fact that in some languages (as most Romance languages, including 
Portuguese) the subjunctive occurs ${ }^{2}$ in complement clauses of factive-emotive predicates, like the equivalents of regret. These predicates are veridical (as seen above, factive predicates are a subset of veridical predicates). If subjunctive signals that the context is non-veridical, it shouldn't occur in the complement clause of these predicates. In fact it does not in languages as Modern Greek or Rumanian, but the same is not verified in other languages which also have the indicative / subjunctive opposition.

In Marques 2009 (see Giannakidou 2015 for a different explanation) the proposal is made that the reason for factive-emotive predicates to take the subjunctive is the counterfactual reasoning that these predicates will involve (cf. Heim 1992) and that the same kind of explanation can be extended to account for the fact that predicates like the equivalents of to manage also take the subjunctive. The proposal advocated there is that subjunctive is licensed by these predicates because, since their meaning involves counterfactual reasoning, non- $p$ worlds are also considered. For instance, if, as Heim 1992 proposes, John regrets that it is raining means that John knows that it is raining and he would prefer that it were not raining, then the meaning of regret (and of the other factive-emotive predicates) includes non- $p$ worlds. Likewise, concerning causative predicates, like to manage, which is also veridical, if causation involves counterfactual reasoning (A cause B means that if A were not the case, all the rest being equal, then B would not be the case either; cf., e.g., Lewis 1973), also the meaning of these predicates leads to the consideration of non-p worlds. A sentence like John managed to open the door conveys the information that John caused the door to be open (if he had not try to open the door, all the rest being equal, the door would not have been opened). Thus, the

\footnotetext{
${ }^{2}$ Or at least may occur. There is some variation within the same language and across languages, but, with the exception of Rumanian, all Romance languages at least admit the subjunctive in the complement of factive-emotive predicates.
} 
meaning of veridical predicates like to manage also involves the consideration of non- $p$ worlds.

In sum, following Giannakidou, and keeping the proposal concerning factiveemotive and causative predicates described in the last paragraph, I assume that the subjunctive signals that at least one non- $p$ world is involved in the meaning of the construction. Given this analysis of the subjunctive, I will now return to the subject obviation issue, which, as seen above, only occurs in some subjunctive complementation structures.

\section{Subjunctive, agentivity and obviation}

Let us begin by recalling that subject obviation occurs with subjunctive complement clauses of verbs of volition, directive and causative predicates. Moreover, as has been observed in the literature (cf., e.g., Ruwet 1991, Quer 1998, Kempchinsky 2009), agentivity also plays a role. As Quer 1998 observes, for co-reference of embedded and main subjects to be possible "the subject of the matrix predicate cannot be the agent in control of the embedded eventuality" (Quer 1998: 51). In fact, if the subject of the main predicate is not the "agent in control" of the embedded eventuality, even with subjunctive complements of verbs of volition, directive or causative predicates co-reference of subjects is more acceptable:

(22) a. [a Ana $]_{i}\{$ quis / pediu / conseguiu $\}$ que [pro $]_{i}$ fosse fotografada '[Ana $]_{\mathrm{i}}\{$ wanted / asked / got $\}$ that $[\text { she }]_{\mathrm{i}}$ was-suвs photographed'

b. $[e l e]_{i}\{$ quis / pediu / conseguiu $\}$ que $[\text { pro }]_{i}$ pudesse entregar o texto mais tarde 
'he $\{$ wanted / asked / got $\}$ that $[\text { pro }]_{i}$ may-SUBJ deliver the text more late'

Maybe something stronger that agentivity is needed. Co-reference of subjects is possible in the following example, where the agent of the embedded eventuality is the same entity as the one identified by the main subject:

tomara $\left\{[\mathrm{pro}]_{\mathrm{i}} /[\mathrm{eu}]_{\mathrm{i}}\right\}$ que $[\mathrm{pro}]_{\mathrm{i} / \mathrm{j}}$ acabasse o trabalhe a tempo!

'I wish that I would finish the task on schedule!'

Ability, as defined by Thomason 2005, apud Giannakidou \& Staraki 2013, may be the relevant condition in Quer's generalization. According to this definition of ability, «Can $x \varphi$ is equivalent to a conditional 'If $x$ tries to bring about $\varphi$, then $\varphi$ '» (Giannakidou $\&$ Staraki 2013: 15). I assume that what Quer has in mind in his generalization is that to be the agent in control corresponds to having the ability, as defined by Thomason 2005 . Quoting Giannakidou \& Staraki 2013, «As Thomason puts it: "In general, ability can depend on favorable circumstances, on the presence of appropriate knowledge, and on non-epistemic properties of the agent. I can truly say I can't write a check either because my bank balance is negative, or because I don't know where my checkbook is, or because my hand is injured. I believe that the same sense of 'can' is involved in each case.” (Thomason 2005: 3).» (Giannakidou \& Staraki 2013: 2).

In sum, the following three conditions lead to subject obviation:

(i) the embedded clause is the complement of a verb of volition, a directive, or a causative predicate;

(ii) the embedded clause is in the subjunctive; 
(iii) the (entity referred by the) embedded subject is the agent in control of the embedded eventuality.

These three conditions need to be jointly observed for obviation to occur. The following examples illustrate this:

(24) a. [a Ana $]_{i}\{$ quis / pediu / conseguiu $\}$ que $[\mathrm{pro}]_{*_{\mathrm{i}} \mathrm{j}}$ abrisse a porta '[the Ana $]_{\mathrm{i}}\{$ wanted / asked / managed $\}$ that $[\text { she }]_{* i / j}$ open-SUBJ the door' b. $[\text { pro }]_{\mathrm{i}}$ duvido que alguma vez $[\mathrm{pro}]_{\mathrm{i} / \mathrm{j}}$ escreva um livro 'I doubt that I ever write-SUBJ a book' c. $[\mathrm{a} A \text { Ana }]_{\mathrm{i}}\{$ quis / pediu para / conseguiu $\}[\mathrm{pro}]_{\mathrm{i}}$ ir à festa 'the Ana $\{$ wanted / asked / managed $\}$ to go-INF to the party' d. $[\text { a Ana }]_{\mathrm{i}}\{$ quis / pediu / conseguiu $\}$ que $[\mathrm{pro}]_{\mathrm{i} / \mathrm{j}}$ fosse fotografada '[the Ana $]_{\mathrm{i}}\{$ wanted / asked / got $\}$ that $[\mathrm{she}]_{\mathrm{i} / \mathrm{j}}$ was-SUBJ photographed'

Non co-reference of subjects is obligatory in (24a), where conditions (i)-(iii) are observed, but not in the other examples. In each of the examples (24b-d), one of the conditions (i)-(iii) is not fulfilled: condition (i) in (24b), (ii) in (24c) and (iii) in (24d).

I believe that agentivity (or better, ability, as defined by Thomason 2005, apud Giannakidou \& Staraki 2013) together with non-veridicality might be the key to explain the obviation data. My intuition is that forcing a co-referential interpretation of embedded and main subjects in examples like (25), below, would somehow lead to a contradiction. It seems that the information would be conveyed that prisoner tried to escape and that he might have not tried: 
[o prisioneiro $]_{\mathrm{i}}$ tentou que $\left[\right.$ pro ${ }_{*_{\mathrm{i}} \mathrm{j}}$ fugisse

'[the prisoner $]_{\mathrm{i}}$ tried that $[\text { he }]_{*_{\mathrm{i} / \mathrm{j}}}$ escape-SUBJ'

To understand what this contradiction might be, let us begin by considering (26), where embedded and main subjects have disjoint reference:

(26) A Ana tentou que o Pedro falasse com a Rita. 'the Ana tried that Pedro talk-SUBJ with the Rita'

The main clause indicates that Ana tried to bring the embedded event into existence. Try is non-veridical (see Giannakidou 2013). It introduces a set of worlds formed by pworlds (i.e., worlds where Pedro talks to Rita) and non p-worlds (worlds where Pedro does not talk to Rita). This subset of non p-worlds might include worlds where Pedro tries to talk to Rita but fails (because Rita refuses to talk to him, because Pedro cannot find Rita, or for some other reason) as it might include worlds where Pedro does not try to talk to Rita. Sentence (26) might be continued in any of the following ways:

(27) A Ana tentou que o Pedro falasse com a Rita.

'Ana tried that Pedro talk-SUBJ to Rita'

a. E ele assim fez.

'And so he did.'

b. Mas ele não a encontrou.

'But he did not find her.'

c. Mas ele recusou-se.

"but he refused" 
The crucial point is that the set of worlds introduced by the main verb includes worlds where the agent of the embedded event does not try to implement this event (hence, the possible continuation (27c)). Given this, if embedded and main subjects were coreferent, the information would be provided that the same entity tried and may have not tried to bring into existence the embedded event. But this is a contradiction. Thus, in (25), non co-reference of subjects is forced. The co-referential reading of embedded and main subjects would amount to express the contradictory information that the prisoner tried to escape plus the information that he might have not tried to escape.

In short terms, the idea is that co-reference of subjects in (25) is impossible because the subjunctive, as seen in the previous section, signals the existence of non-p worlds in the context where it occurs, some of which may be worlds where the agent of the event does not try to perform the event, while the main clause indicates that he does.

But, even if this idea can explain (25), with the obviative predicate try, is it extendable to constructions with other obviative predicates, namely other causative predicates, verbs of volition and directives? If these predicates allowed the inference 'if $\mathrm{x}$ \{wanted / asked / managed $\} p$, then $\mathrm{x}$ tried $p^{\prime}$, the explanation for obligatory non co-reference of embedded and main subjects could be the same as the one sketched for (25).

Concerning directive predicates, as to ask or to order, it could be proposed that the event of asking or ordering is an attempt to bring into existence what is asked or ordered. That is, if John asked Mary to leave, then he tried her to leave. Likewise, it is usually assumed that to manage presupposes to try (and the same can presumably be said about other causative predicates, like to force or to make happen, unless the main subject refers to a non rational entity, as in the storm forced us to go back). However, the explanation envisaged for (25) does not seem to be extendable to other causative 
predicates (a subject to which I will return below) and seems also problematic when predicates of volition come into consideration.

\subsection{Predicates of volition}

Giannakidou \& Staraki 2013 consider the notion of force, provided by Copley and Harley 2010:

«"A force is an input of energy into some initial situation. This energy is either generated by an animate entity, or it comes from the motion or properties of an inanimate object. The application of this energy changes the initial situation into a different situation, as long as no stronger force keeps it from doing so.... A force's observed final situation is thus contingent on the existence and strength of other forces opposing it." Copley and Harley 2010 (section 3).

In C\&H's framework, an event is to be understood as force that brings about a result (provided that nothing external intervenes). Forces are, in the most obvious case, physical forces, i.e. contact forces that result in change in the spatiotemporal properties of the object (i.e. in movement or rest, etc). (...) The innovation in $\mathrm{C} \& \mathrm{H}$ is the idea that psychological forces, i.e. desires, intentions, and, we will suggest, ability, can also function as physical forces in bringing about change. Surely, though, psychological forces are not ontologically identical to physical forces: intentions and desires involve an agents' beliefs and thoughts, and are not physical themselves.» (Giannakidou \& Staraki 2013, p. 18) 
Giannakidou 2013 shows that try does not involve physical action. A nice example she presents is the following:

(28) Context: John is severely injured and cannot move his arm: John tried to raise his arm. (But he didn't.)

In her words, "TRY is device that triggers a transition from pure intention (psychological force) to an action path. The TRY path thus includes physical force, i.e. actions of an agent in order to materialize the intention, but also an initial stage of mental force where no physical action has taken place. If we go back to the injured person example, trying to raise her hand, we see that it is possible for a TRY-path to refer exclusively to this initial stage of intention, without physical realization at all." (Giannakidou 2013: 20)

So, if try refers to a path that initiates with mental force and if, as Copley and Harley 2010 propose, desires are forces, it might be considered that $x$ wanted $p$ allows the inference that $x$ tried $p$. This seems to be in accordance with Copley 2010, apud Giannakidou \& Staraki 2013:

«Law of Rational Action (Copley 2010: (16))

If a volitional entity intends something in a situation $s$, and is not prevented by anything from acting in such a way (according to his/her beliefs) as to achieve it, the being acts (exerts a force on $s$ ) in such a way (according to his/her beliefs) to achieve it.» (Giannakidou 2013: 18)

However, Giannakidou \& Staraki 2013, as well as Giannakidou 2013, argue against such possibility: 
«It is important to understand what the law of rational action motivates. It says that whenever there is a volitional agent and the agent intents an action, this intention, if nothing else prevents it, will become force. In this general sense, the law is admittedly too strong - since in the normal case, it just doesn't follow from $x$ wanting or intending something that $x$ will act upon her desire. (...) And conceptually, it is simply true that one may never act on a desire even if there are no forces preventing action.» (Giannakidou \& Staraki 2013: 18, my underline)

«Having a desire by itself does not necessarily entail acting on the desire and I may well have desires that I know cannot be acted upon. So, although desires and intentions are forces, they do not involve action themselves, physical or mental, and are therefore nonveridical.

Kamp describes the difference between intentional verbs like try and pure volitionals as follows: "The situation is different with verbs such as want, wish, and desire. These verbs do not claim the existence of an intention, you can wish or desire to open the door without having an actual intention to that effect. [...] In the semantic contribution of the to-complements of these verbs, we do not want any intention at all, in particular we do not want the one that comes from the action verb." (Kamp 1999-2007: 63). In other words, want is a nonveridical verb without intention for action, but TRY is a nonveridical verb with intention for action.» (Giannakidou 2013: 19) 
It is unquestionable that having a desire does not imply acting on the desire (i.e., want does not necessarily imply try). But it also seems reasonable to say that sometimes desires can be a force (as defined by Copley and Harley 2010) that leads to action. There are, of course, other forces, apart from desires, that may lead to action (for instance, one may be obliged by someone else or by the circumstances to do something against the own desires). That is, try does not imply want, either. In sum, want does not imply try, neither try implies want, but they are compatible with each other. Moreover, if a desire can be (though it does not have to be) a force that triggers action, also $x$ not wanting to do $\varphi$ may lead $x$ to not try to do $\varphi$. That is, not wanting $p$ might be a reason for not try $p$.

Given this, let us consider the following sentence and continuations of it:

(29) A Ana quis que o Pedro falasse com a Rita.

'Ana wanted that Pedro talk-SUBJ to Rita'

a. E ele falou.

'And he did it.'

b. Mas ele não a encontrou.

'But he did not find her.'

c. Mas ele não quis.

"But he didn't want to."

(29c) allows the inference that Pedro didn't even try to talk to Rita, whereas (29a) and (29b) convey the information that he tried (successfully or unsuccessfully). In other words, the meaning of querer que $\mathrm{p}$ ('to want that $\mathrm{p}$ ') contains $\mathrm{p}$-worlds and non-p worlds, some of the non-p worlds being worlds where the agent of the embedded event 
does not want to bring the event into existence (hence the possible continuation of the sentence in (29c)). Therefore, if the embedded and the main subjects were co-referent, a contradiction would be expressed: the information would be conveyed that $x$ wants $p$ (i.e., all worlds that conform to $x$ 's desires are $p$-worlds) and $x$ may not want $p$ (as shown by (29c), the complement of want includes worlds where the embedded subject does not want to act towards the realization of the embedded event). Hence, in (30) the embedded subject cannot have the same reference as the main subject:

(30) $\quad[\mathrm{a} \text { Ana }]_{\mathrm{i}}$ quis que $[\mathrm{pro}]_{*_{\mathrm{i} / j}}$ saísse

'[Ana $]_{\mathrm{i}}$ wanted that $[\mathrm{pro}]_{*_{\mathrm{i}} \mathrm{j}}$ leave-SUBJ'

Why, then, is it possible embedded and main subjects to be co-referent if the main clause's subject is not an entity that can bring into existence the state of affairs described by the embedded clause, as in the following example?

(31) [a Ana $]_{i}$ quer que $[p r o]_{i / j}$ seja recrutada pelo Exército (não pela Armada) '[Ana $]_{\mathrm{i}}$ wants that $[\mathrm{pro}]_{\mathrm{i} / \mathrm{j}}$ be-SUBJ recruited by the Army (not by the Navy)'

Since querer que $p$ ('x want that p') includes $p$-worlds and non $p$-worlds, and, as seen above, some of these non-p worlds are worlds where the embedded subject does not want to bring into existence the state of affairs described in the embedded clause, also (31) indicates that all worlds that conform to Ana's desires are worlds where she is recruited by the Army and some worlds that conform to her desires are worlds where she isn't recruited. So (31) should also express a contradiction. However, the sentence is fine. 
Still, if $x$ want $p$ does not mean that in all worlds that conform to $x$ 's desires are $p$ worlds, but, as Heim 1992 proposes, that, for $x, p$-worlds are better than non $p$-worlds, in (31) this amounts to say that, even if Ana would prefer not to be recruited at all, if she has to be enlisted, then she prefers to be recruited by the Army than to be recruited by the Navy. This seems to be compatible with the consideration of non $p$-worlds where the embedded subject does not try to bring into existence the embedded eventuality. In some worlds she does not try to be recruited because she does not want to be. That is, if, as Heim proposes, want involves an ordering of preferences, (31) means that, for Ana, worlds where she is recruited by the Army are better than worlds where she is recruited by the Navy, and maybe in the best (for Ana) worlds she is not recruited either by the Navy or by the Army. In the best worlds, Ana does not try to be recruited because she doesn't want to be. In simple terms, co-reference of subjects in (31) would be possible because the consideration of non p-worlds where Ana does not try to be recruited by the Army (because she does not want to be) are not in conflict with the information that she prefers to be recruited by the Army than to be recruited by the Navy.

Contrasting with (31), in examples like (30), since Ana is the agent in control of the embedded eventuality, the consideration of non p-worlds where she does not try to leave plus the information, provided by the main clause, that she wants to leave is incongruous. Forcing co-reference of subjects in (30) would express the odd information that Ana wants to leave, she can leave, and maybe she does not try to leave because she does not want to leave.

In summary, both for cases with the main verb try as for cases with predicates of volition, the sketched hypothesis is that co-reference of subjects is ruled out because the subjunctive complement signals the consideration of non p-worlds, some of which are worlds where the embedded subject does not want to bring the embedded eventuality 
into existence, but the same entity has the ability to do the embedded event and the main clause informs that (s)he tries or wants to do it. Let us now consider other obviative predicates.

\subsection{Directive and causative predicates}

Above, the hypothesis was ventured that obviation with causative predicates like (the equivalents of) to manage was due to the same reason why obviation occurs with try. However, at first sight such hypothesis doesn't seem to be sustainable.

Concerning constructions with tentar ('to try'), the proposal was made that embedded and main subjects may not refer to the same entity because this would lead to the absurd information that the same entity tried and may have not tried to perform the embedded eventuality. But causative predicates like conseguir ('to manage') are veridical, while tentar ('to try') is non veridical. Sentence (26), repeated below as (32), allows the possibility that Pedro did not try to talk to Rita, but (33) does not allow this inference:

(32) A Ana tentou que o Pedro falasse com a Rita.

'the Ana tried that Pedro talk-SUBJ with the Rita'

Mas ele nem tentou.

'But he didn't even try.'

(33) A Ana conseguiu que o Pedro falasse com a Rita.

'the Ana managed that Pedro talk-SUBJ with the Rita'

\#Mas ele nem tentou.

'But he didn't even try.' 
The complement of manage does not include worlds where the subject did not try to perform the embedded eventuality. Therefore, with predicates as (the equivalents of) to manage obviation cannot be explained as following from the contradiction, that coreference of subjects would lead to, that the same entity tried and may have not tried to do $p$.

However, both (32) as (33) allow the inference that maybe Pedro did not want to talk to Rita. Any of these sentences can be continued with although he didn't want to [talk to Rita]. Additionally, $x$ conseguir $p$ (' $x$ manage $p$ ') allows the inference that maybe $x$ wants $p$. Therefore, co-reference of subjects in (34), below, would lead to contradictory information:

(34) [A Ana $]_{\mathrm{i}}$ conseguiu que $[\mathrm{pro}]_{*_{\mathrm{i} / j}}$ falasse com a Rita

'[the Ana $]_{i}$ managed that [pro $]_{* i / j}$ talk-SUBJ with the Rita'

Co-reference of subjects would allow the inference that Ana might have wanted and not wanted to talk to Rita.

Likewise, directive predicates allow the inference that if $x$ \{asked / ordered / requested / ... that $y$ do $\varphi$, then $x$ expressed the will that $y$ do $\varphi$, even if $y$ does not want to do $\varphi$. Consequently, if $x$ and $y$ are the same entity, the anomalous information is conveyed that the same entity might have and not have the desire of doing $\varphi$. Hence, obviation occurs.

\section{Conclusion}


In this paper a semantic explanation for (subject) obviation was sketched. As has been stressed in the literature, obviation occurs in subjunctive complementation structures of three classes of predicates: verbs of volition, directives and causatives. Some of these predicates (e.g., try, manage) indicate that the main subject tries to bring into existence the embedded eventuality. Other obviative predicates (e.g., want) indicate the desire of the main subject that the embedded eventuality comes into existence. On the other hand, a subjunctive complement signals the consideration of worlds where the embedded eventuality does not come into existence (i.e., the subjunctive signals the existence of non p-worlds) and one reason for the embedded eventuality not to become into existence is the agent of the eventuality not wanting to try. Therefore, if main and embedded subjects refer to the same entity and this entity is the agent of the embedded eventuality, the information is conveyed that the same entity tried to do $p$ and maybe did not try to do $p$ or that the same entity wants $p$ and maybe does not want $p$. In either case, the information is contradictory. Hence, co-reference of subjects is avoided.

\section{Acknowledgement}

I am very thankful to the organizers of the book and to the reviewers of a previous version of this text, in particular to Anastasia Giannakidou, for very relevant and helpful comments.

\section{References:}

Ambar, M. (1992). Temps et structure de la phrase en portugais. In Hans Obenhauer \& Anne Zribi-Hertz (eds.). Structure de la phrase et Théorie du Liage (pp. 29-49). Saint-Denis: Presses Universitaires de Vincennes. 
Farkas, D. (1992). On obviation. In: Sag, I.A., Szabolsci, A. (eds.). Lexical Matters (pp. 85-109). Stanford, CA: CSLI Publications.

Giannakidou, A. (1998). Polarity Sensitivity as (Non)veridical Dependency. Amsterdam-Philadelphia: John Benjamins.

----- (2013). The subjunctive as evaluation. For J. Blaszack, et al. (eds.). Tense, Mood, and Modality: New Perspectives on Old Questions, (http://home.uchicago.edu/ giannaki/papers.html).

Giannakidou, A. \& E. Staraki (2013). Ability, action, and causation: from pure ability to force. To appear in Mari et al. (eds), Genericity, OUP.

Giorgi, A., F. Pianesi (1997). Tense and Aspect: From Semantics to Morphosyntax. Oxford: Oxford University Press.

Heim, I. (1992). Presupposition Projection and the Semantics of Attitude Verbs. Journal of Semantics, 9.3, 183-221.

Kempchinsky, P. (1986). Romance subjunctive clauses and logical form. Ph.D. dissertation, UCLA.

----- (2009). What can the subjunctive disjoint reference effect tell us about the subjunctive?. Lingua, 119, 1788-1810.

Lewis, A. (1973). Counterfactuals. Harvard University Press.

Laca, Brenda (2010). Mood in Spanish. In B. Rothstein \& R. Thieroff (eds.). Mood in the languages of Europe (pp. 198-220). Amsterdam-Philadelphia: John Benjamins.

Marques, R. (2009). On the selection of mood in complement clauses. In L. Hogeweg, H. de Hoop \& A. Malchukov (eds.). Cross-linguistic Semantics of Tense, Aspect, and Modality (pp. 179-204). Amsterdam-Philadelphia: John Benjamins.

----- (2014). Référence au réel et concordance des temps en portugais européen. Travaux linguistiques du Cerlico, 27, 31-46. 
Marques, R., P. Silvano, A. Gonçalves \& A. L. Santos (2015). Sequence of tenses in complementation structures: lexical restrictions and effects on language acquisition. R. Klassen, J. M. Liceras \& E. Valenzuela (eds.). Hispanic Linguistics at the Crossroads - Theoretical linguistics, language acquisition and language contact (pp. 6988). Amsterdam-Philadelphia: John Benjamins.

Oliveira, F. (2003). Modalidade e modo. In M. H. M. Mateus et al. Gramática da Língua Portuguesa, 5. ${ }^{\text {th }}$ ed. (pp. 243-272). Lisboa: Caminho.

Picallo, C. (1984). The Infl Node and the Null Subject Parameter. Linguistic Inquiry, $15,75-101$.

Quer, J. (1998). Mood at the interface. Ph.D. dissertation. UiL OTS/Universiteit Utrecht.

----- (2001). Interpreting mood. Probus, 13, 81-111.

Raposo, E. (1985). Some asymmetries in the Binding Theory in Romance. The Linguistic Review, 5 (1), 75-110.

Ruwet, N. (1984). Je veux partir/*Je veux que je parte. Cahiers de grammaire, 7. Toulouse: Le Mirail.

Ruwet, N., 1991. Syntax and Human Experience. University of Chicago Press, Chicago. Speas, M. (2004). Evidential paradigms, world variables and person agreement features. Rivista di Linguistica, 16, 253-280.

Vogel, R. (1997). Aspects of Tense. The Hague: Holland Academic Graphics. 